\title{
STUDIES OF PALEOZOIC FUNGI. IV. WOOD-DECAYING FUNGI IN CALLIXYLON NEWBERRYI FROM THE UPPER DEVONIAN ${ }^{1}$
}

\author{
Sara P. Stubblefield ${ }^{2}$ Thomas N. TAYlor, ${ }^{2}$ AND \\ Charles B. BeCK ${ }^{3}$ \\ ${ }^{2}$ Department of Botany, The Ohio State University, Columbus, Ohio 43210; and \\ ${ }^{3}$ Museum of Paleontology and Division of Biological Sciences, The University of Michigan, \\ Ann Arbor, Michigan 48109
}

\begin{abstract}
A B S T R A C T
An extensive fungal infection is present in silicified specimens of Callixylon newberryi (Dawson) Elkins and Wieland from the Upper Devonian of Indiana. Fungi are represented by branched, septate filaments with both terminal and intercalary chlamydospores. Clamp connections were not observed. Tracheids of the secondary xylem, decayed in varying degrees, show erosion troughs, cavities, and extensive lysis of tracheid walls. The pattern of decay is most similar to modern-day white rots, which are typically caused by basidiomycetes, while hyphal features are characteristic of either ascomycetes or basidiomycetes. The presence of wood decay coupled with a septate mycelium suggests the presence of higher fungi in the Devonian and indicates a more diverse Devonian mycoflora than has previously been recognized.
\end{abstract}

THE DeVONIAN MYCOFLORA is poorly known. Although a few fungi have been reported from marine environments (e.g., Fry and McLaren, 1959; Taylor, 1971), the mycoflora associated with early land plants is known almost entirely from silicified specimens in the Rhynie Chert (Kidston and Lang, 1921; Harvey, Lyon, and Lewis, 1969; Boullard and Lemoigne, 1971; Illman, 1984) and similar calcified material from the Gaspé Peninsula (Stubblefield and Banks, 1983). In the present paper an additional occurrence of Devonian fungi is documented. An extensive fungal infection is described in the tracheids and ray cells of the Upper Devonian progymnosperm Callixylon newberryi (Dawson) Elkins and Wieland. Hyphae were first noted in this material by Arnold (1931), who published a single light micrograph of infected tracheids during the course of an anatomical investigation of Callixylon newberryi. Reinvestigation of material from this locality offers the opportunity to study both the earliest known fungi in wood as well as the

\footnotetext{
' Received for publication 3 December 1984; revision accepted 14 June 1985.

The authors with to thank Dr. Roland L. Seymour of the Department of Botany, The Ohio State UniversityColumbus, and Dr. Robert L. Shaffer of the Herbarium, The University of Michigan-Ann Arbor for much useful discussion. This research was supported in part by funds from the NSF (DEB-8213060).

We wish to dedicate this paper to our colleague, the late Dr. Charles E. Miller of Ohio University, Athens, $\mathrm{OH}$ who worked closely with us in several studies on fossil fungi. Chuck Miller's cherished friendship, and his enthusiasm and in-depth understanding of fungi will continue to serve as an inspiration for our work.
}

earliest known example of wood decay caused by fungi, and also suggests the presence of higher fungi in the Upper Devonian.

MATERIALS AND METHODS-Fungi occur in the secondary xylem of a block of silicified Callixylon newberryi collected $5 \mathrm{mi}$ northeast of Henryville, Clark County, IN. The fragment of wood comes from the upper portion of the Blackiston Formation in the New Albany Shale. This part of the formation is Upper Devonian in age and corresponds to the European $\mathrm{Fa}$ mennian stage (Collinson, 1967). The specimen is no. 13834 in the Museum of Paleontology, The University of Michigan-Ann Arbor. Peels and thin sections from this specimen bear nos. $13834-1$ to $13834-20$ in the same collection.

Material was prepared for light microscopy both as ground thin sections and as cellulose acetate peels in which concentrated hydrofluoric acid was substituted for hydrochloric acid. In preparation for scanning electron microscopy (SEM), specimens were etched for 2 4 min with concentrated hydrofluoric acid and rinsed in water until neutral. Material was then dried in a critical point dryer, mounted on standard stubs, and coated with both carbon and gold. The use of carbon significantly reduced charging (Skog, 1983).

DESCRIPTION-The infected specimen is a block of secondary xylem approximately 100 $\mathrm{cm}^{3}$ in size from the progymnosperm Callix$y$ lon newberryi. Due to the fragmentary nature 


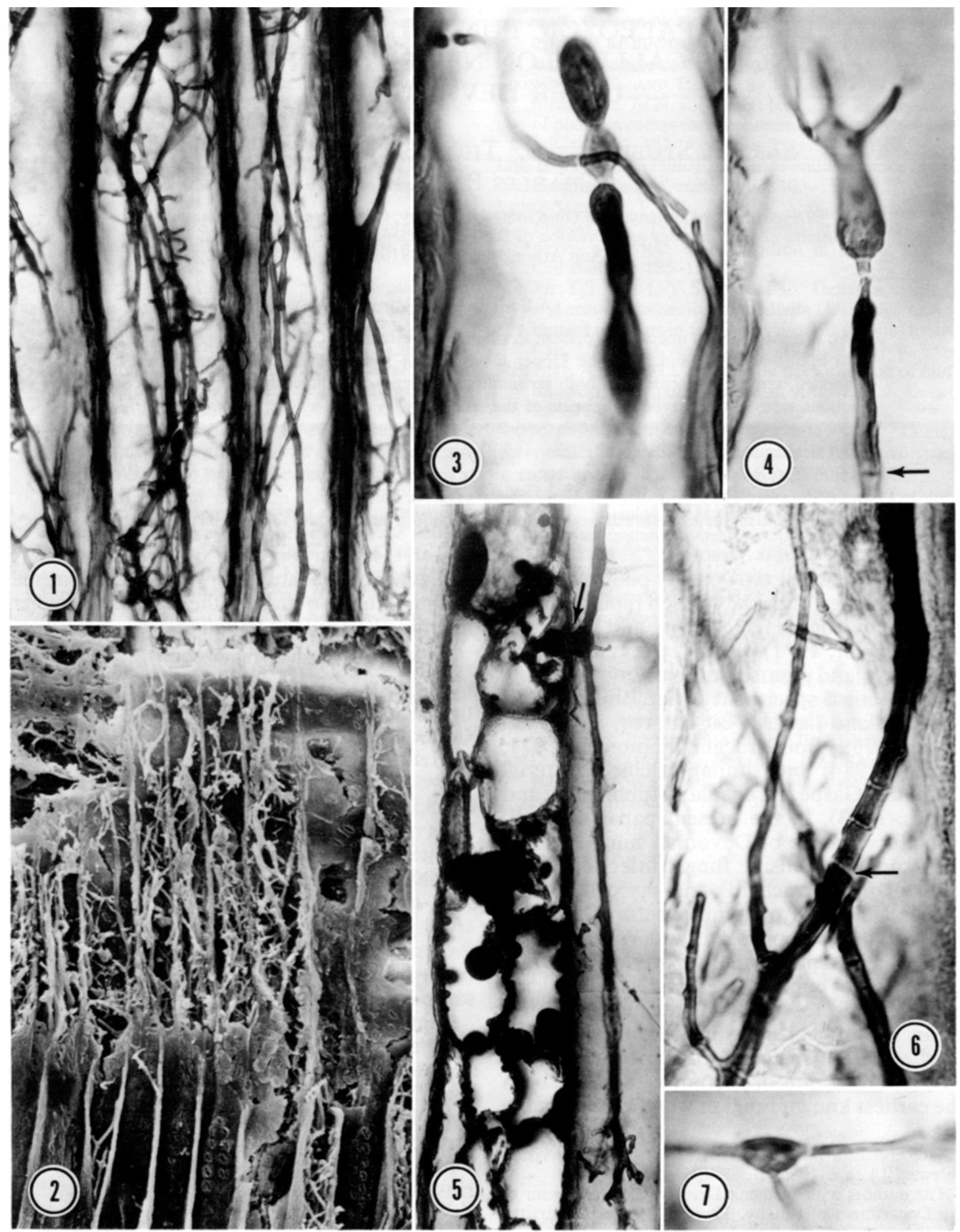

Fig. 1-7. Fungal hyphae in Callixylon newberryi. 1. Tangential section of tracheids with fungal hyphae. $\times 430.2$ Tracheids containing fungal hyphae; note abundance of fungi. $\times 200.3$. Terminal chlamydospores. $\times 2,600$. 4. Septate hyphae (arrow) with terminal chlamydospore germinating at three points. $\times 2,600.5$. Radial section of ray cells on left and tracheid on right. Note continuity of hyphae between ray and tracheid (arrow) and small projections from hyphae. $\times 600.6$. Branched, septate hypha. Arrow at pseudoseptum formed by break. $\times 700.7$. Hypha with intercalary swelling $\times 2,600$. 
of the specimen, the original extent of the infection cannot be determined. Fungal hyphae are abundant in both tracheids and ray cells, and in each case they are generally oriented parallel to the long axis of the infected cell (Fig. $1,2,5,24-27)$. In some instances entire ray cells may be occluded by hyphae.

Hyphal morphology varies, particularly in respect to size, branching, and surface texture. Hyphae range from $1.5-6 \mu \mathrm{m}$ in diam. In ground sections they often appear flat and ribbonlike (Fig. 1). Twists in the filament create the superficial appearance of changes in diameter, although hyphal swellings do occur (Fig. 9). Septae are present (Fig. 1,6), although many apparent septae are nothing more than breaks in the filament (Fig. 4 and 6 at arrow). Frequently branched hyphae are common (Fig. 1, $2,6)$ and sometimes intertwine forming a dense mass within infected cells (Fig. 1, 2). Hyphal branches are sometimes narrower than the parent filament (Fig. 6), but dichotomous branching is present. Other hyphae are unbranched for a considerable length except for short, narrow lateral extensions (Fig. 5). In some cases these hyphae produce a highly divided lateral branch (Fig. 5 at bottom). In transmitted light, hyphal surfaces are either smooth (Fig. 1-7) or rough (Fig. 19, 20). When scanned, even the smoothest surfaces are uniformly rough (Fig. $8-10$ ), while rougher hyphae bear discrete rounded knobs along their surfaces (Fig. 11). Both single intercalary swellings (Fig. 5, 7, 9 at arrow, 26), and single (Fig. 4) and multiple terminal swellings (Fig. 3) occur. Typically, such swellings branch at several points (Fig. 4, 7, 9).

The tracheid walls of infected Callixylon are particularly interesting and show evidence of fungal modification. Preservation is generally excellent, and the inner walls are often nearly smooth or slightly cracked (Fig. 8, 9, 12 at left). However, many tracheids are extensively decayed. Decay features include long, narrow grooves (Fig. 17 at arrows), oval cavities (Fig. 14), and severely degraded wall surfaces (Fig. $12,13)$. The walls of ray cells appear to be unmodified.

An additional distinctive feature of this wood is the contents of the ray cells. Three types of bodies are present. In transmitted light the most obvious structures are dark brown or amber, and spherical, elongate, or irregular in shape (Fig. 15, 20, 21). Spherical bodies range from $1.8-50.0 \mu \mathrm{m}$ in diam. They are often solid, but single hollow specimens and vesicular bodies are also prevalent. A smooth surface is most commonly observed, although rough spheres are also present. These structures appear to be of the same material as closely associated irregular meshlike deposits on the inner surfaces of ray cells. The second type of cellular inclusion is distinguishable from the first only by the presence of a clear surrounding zone bounded by a layer with a rough outer surface (Fig. 15, 16, 18, 21). The thickness of this transparent layer varies, reaching $0.36 \mu \mathrm{m}$. This layer also encloses rods and irregularly shaped pieces of the brown-amber material (Fig. 21). The third type of cellular inclusion consists of spherical bodies $10-23 \mu \mathrm{m}$ in diam, which often appear collapsed (Fig. 22, 23). All three types are found primarily in the ray cells (Fig. 15, $16,18,22$ ), although some have been observed in tracheids (Fig. 23).

DiscusSION-The discovery of a well-developed mycelium coupled with degraded tracheids in Devonian wood raises a number of interesting questions concerning the nature of the interaction between the fungus and the vascular plant, the nature of the fungus itself, and fungal evolution. In many instances involving fossil fungi it is impossible to determine the kind of relationship that existed between the fungus and the plant with which it was associated. However, information about the role of the fungus in Callixylon is suggested by the

Fig. 8-14. 8-11. Fungal hyphae. 12-14. Degraded tracheid walls. 8. Branching hyphae on inner wall of tracheid. Note relationship between hyphae and pits on tracheid wall. $\times 2,500.9$. Branching hyphae in two adjacent tracheids. Note intercalary swelling (arrow) and encrusting material on hyphae. $\times 1,200.10$. Hyphae with rough surfaces. $\times 600$. 11. Hyphae with rounded bodies on surfaces. $\times 5,500$. 12. Tracheid with degraded wall. Compare with intact wall containing longitudinal crack on left. $\times 2,000.13$. Degraded wall of tracheid showing irregular pattern caused by extensive lysis. $\times 2,000$. 14. Tracheid with ellipsoidal regions of degradation. $\times 1,500$.

Fig. 15-20. 15, 16, 18. Cell contents. 17. Degraded cell wall. 19, 20. Hyphal morphology. 15. Ray parenchyma with globular contents. Note hyaline regions around some spheres. $\times 660.16$. Note surface texture and variability in shape in contents of ray cells. $\times 800$. 17. Inner surface of tracheid wall illustrating pits, crack, and narrow grooves (arrow). $\times 1,500.18$. Globules in ray cells. Note that globules contain an outer, clearly defined wall. $\times 900.19$. Rough fungal hyphae with closely associated spherical inclusions. $\times 2,000.20$. Rough fungal hyphae in ray parenchyma. $\times 2,000$. 


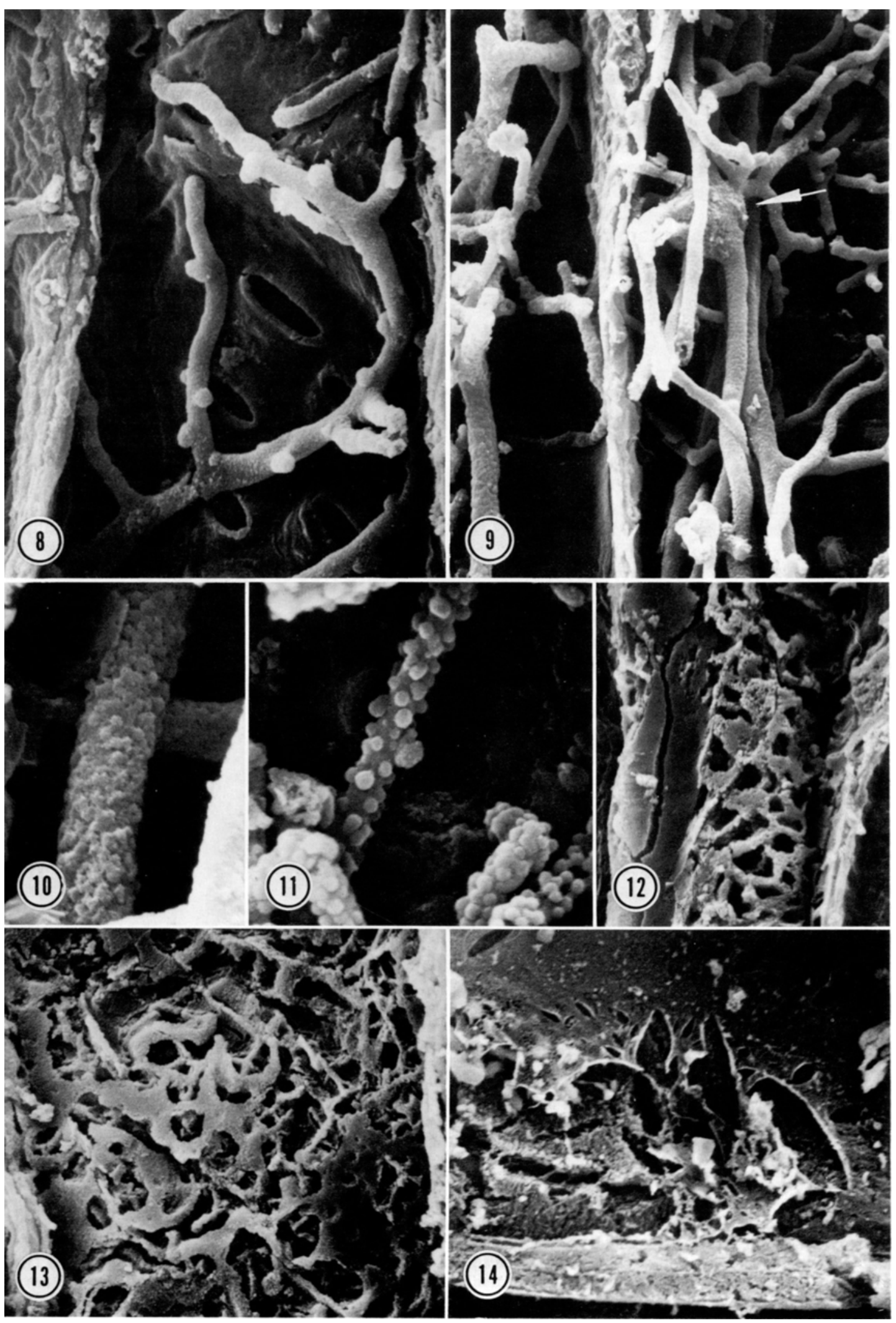



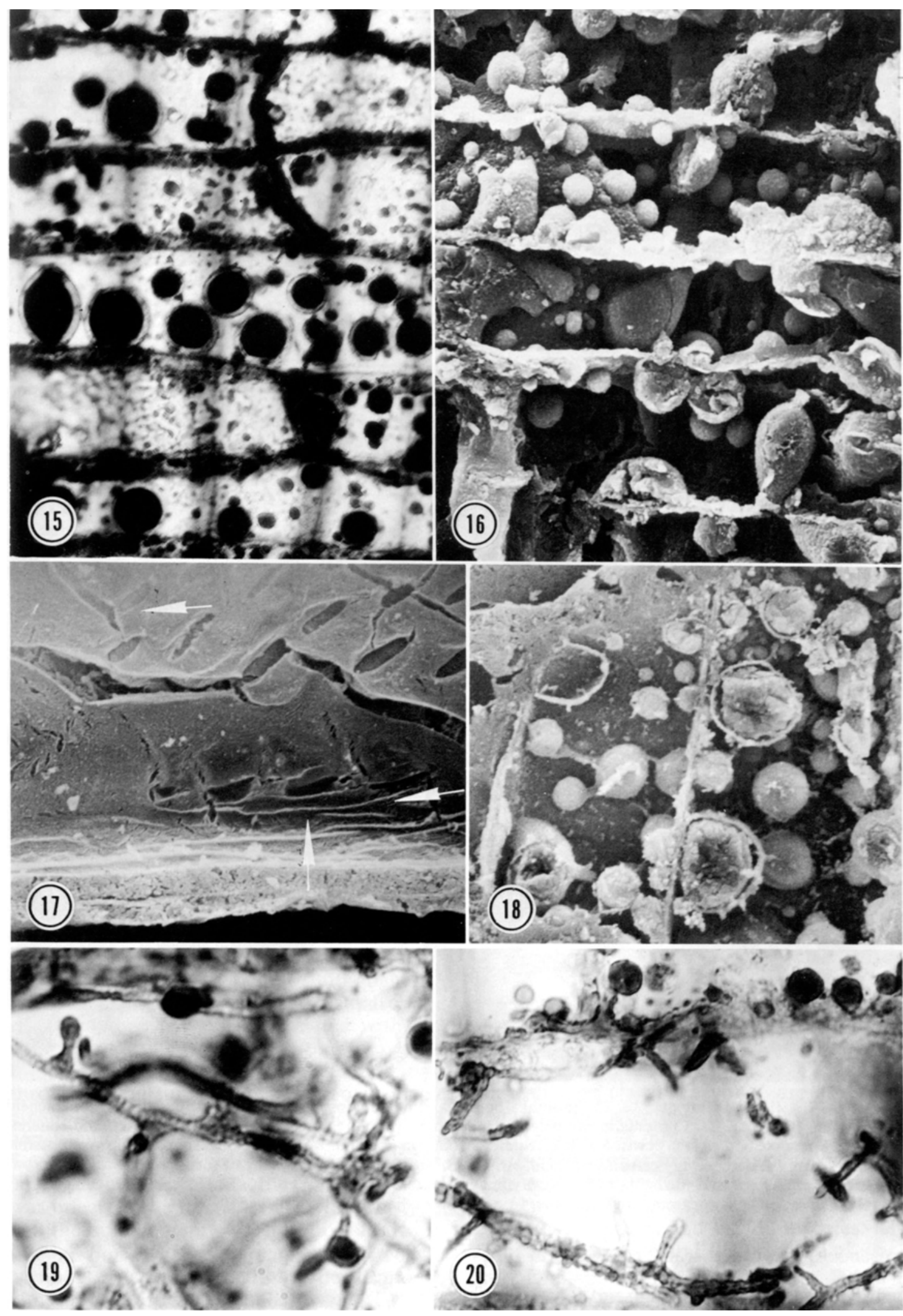

(19) at 4

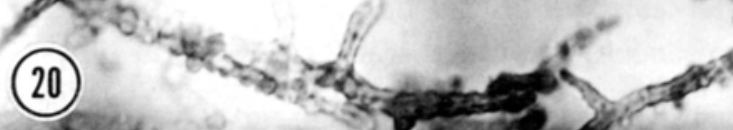




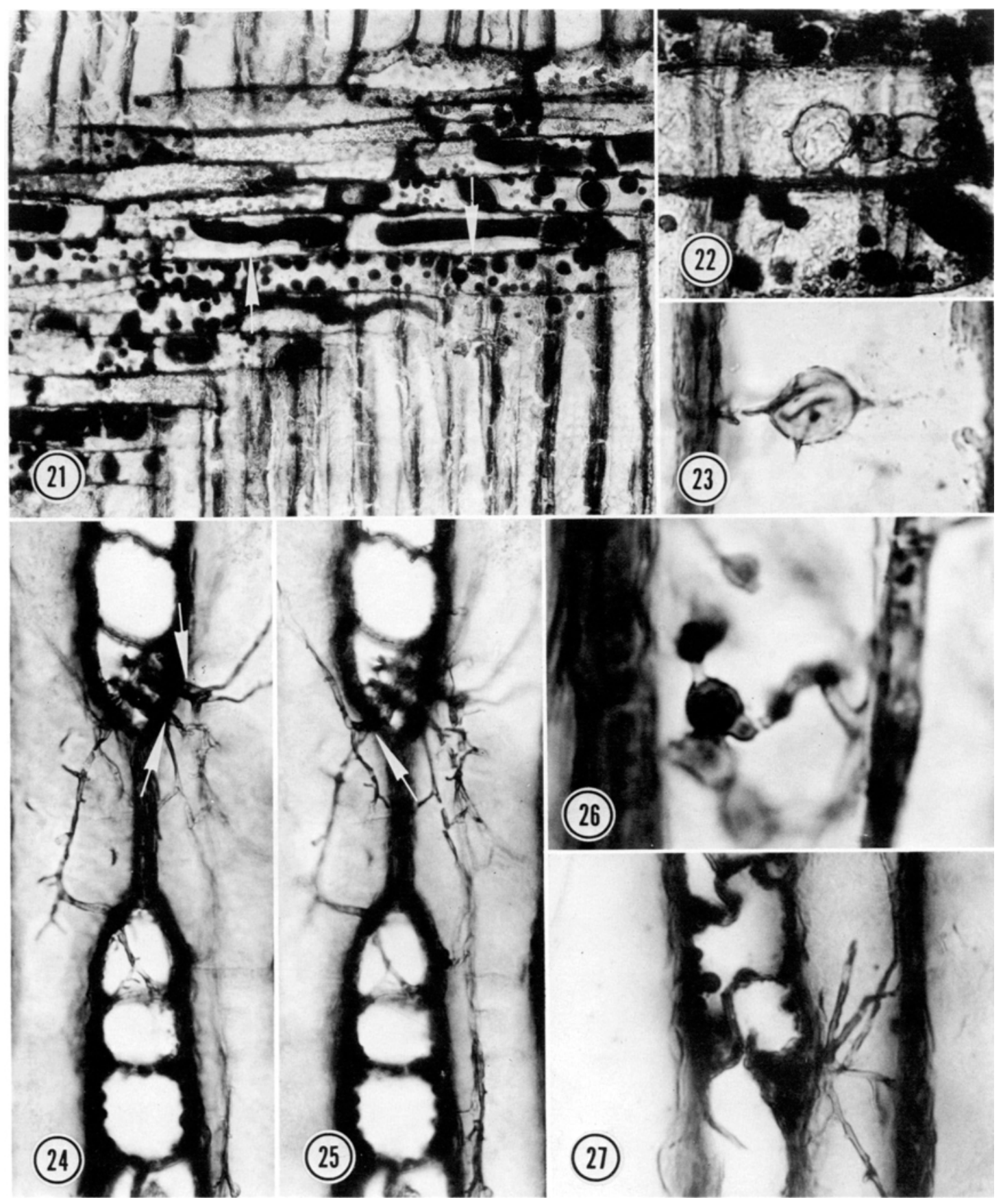

Fig. 21-27. 21. Cell contents. 22, 23. Sporelike bodies and chlamydospores. 24, 25, 27. Penetration of tracheid walls by fungal hyphae. 21. Contents in ray parenchyma. Note hyaline regions around rodlets (arrows) and spheres. $\times 330.22$. Sporelike bodies in ray cells. $\times 525.23$. Sporelike body in tracheid. $\times 670.24$. Fungal hyphae showing possible continuity (arrows) between ray cell and tracheid. $\times 650.25$. Fig. 24 in different plane of focus. Hypha at left (arrow) passes between ray cell and tracheid. $\times 650.26$. Hypha with chlamydospores. $\times 1,700.27$. Tracheid and adjacent ray cell. Hyphae in tracheid apparently radiate from a single point adjacent to ray cell. $\times 650$.

presence of degraded tracheids. Several types of wood decay effect extant woods, including soft rots, white rots, and brown rots, each of which differs in the pattern of decay, the types of wood-decaying fungi involved, and the biochemical activity of the fungi (Montgomery, 1982). Because chemical tests are not presently feasible with permineralized woods, morpho- 
logical features, especially of the degraded walls and the fungi themselves, provide the only information concerning the type of wood decay.

In the past $20 \mathrm{yr}$, scanning electron microscopy has been widely used to study decaying woods and has contributed significantly to the recognition of different types of decay in modern woods (e.g., Findlay and Levy, 1969; Bravery, 1971; Jutte and Zabel, 1974; Eriksson et al., 1980). Soft rots, first recognized by Savory (1954), are typically caused by ascomycetes or imperfect fungi. The invading fungus forms chains of cavities with pointed ends that parallel the cellulose microfibrils in the $S_{2}$ layer of the cell wall, and it penetrates adjacent cells by the formation of fine hyphal strands termed proboscis hyphae (Corbett, 1965; Jutte and Zabel, 1974). White and brown rots are both caused by basidiomycetes. White rot fungi decay the secondary wall by the production of erosion troughs along the path of the hyphae, which eventually coalesce and severely erode the wall (Bravery, 1971). Brown rots produce an amorphous decay, which has been described as looking "more like expanded polystyrene or foam rubber than the normal smooth texture of the unattacked walls" (Levy, 1982). Phycomycetes may also be found in wood as "primary moulds" that live from simple carbohydrates derived from the ray parenchyma or soil, but they do not have the capacity to penetrate wood except through natural openings or cavities caused by other organisms and are not regarded as wood destroyers (Levy, 1982).

In the present material the pattern of decay is unlike that typically associated with brown rot. Furthermore, it differs from most soft rots. Hyphae are not generally found within the tracheid walls, and although pointed cavities are present, they are produced only in the inner surface layers of the wall and their orientation differs from that produced by soft rot fungi. In addition, the small cavities caused by proboscis hyphae have not been found, although they may be difficult to distinguish from small cracks resulting from processes associated with fossilization. Hyphae typically extend along the inner wall surface of the tracheid and pass through the cell lumen. The pattern of probable erosion troughs on decayed tracheid walls is consistent with the coalescing of these troughs. Severe lysis is also evident in some tracheids. These features suggest that the Callixylon wood was infected by a fungus of the white rot type, and the involvement of basidiomycetes is implied. Several authors have provided excellent scanning electron micrographs of white rot decay in several different extant woods, which may be examined for comparison (e.g., Brav- ery, 1971; Jutte and Zabel, 1974; Levy, 1974; Eriksson et al., 1980).

The means by which hyphae penetrate the tracheids and ray cells of Callixylon is not clear. The fungal infection is extensive, and the majority of cells contain fungi. In many instances, cells, particularly those of the ray parenchyma, are completely occluded. The degree of infection is easily underestimated in SEM preparations since fungi are often lost during the etching process when an entire column of silica, which encases fungi, falls from a cell cavity. However, despite the fact that the fungi have ramified throughout the entire block of xylem, it is unusual to see hyphae passing from cell to cell. There is no indication that they passed through pits, although this is a common route for white rot fungi (Bravery, 1971). In fact, in all our SEM preparations, hyphae pass over, but not through the pits (e.g., Fig. 8). Bore holes are not obvious, but they are sometimes uncommon in modern examples of white rot as well (Bravery, 1971). Several observations suggest that hyphae pass from rays to tracheids. In the most convincing cases, a hypha in a tracheid seems to be continuous with a structure in an adjacent ray cell (Fig. 5, 24, 25). In other cases, the only hyphae in a tracheid appear to originate from a single point next to a ray cell (Fig. 5, 27). It is possible, therefore, that the rays provide the main passageway for the movement of fungal mycelium throughout the wood. Since all tracheids are probably in contact along their lengths with one or more rays, all tracheids in a region of wood could contain the fungus without any hyphal penetration through the walls of contiguous tracheids.

The fungus in Callixylon is interesting in several respects. The infected wood contains the most well-preserved hyphae presently known from the Devonian, and the oldest wood-inhabiting fungus. The septate mycelium is both extensively developed and well preserved. Clamp connections were carefully sought, but none were demonstrated to our satisfaction, although occasional bulges along hyphal margins (see Fig. 6) may sometimes be suggestive of clamps. Hyphae are also characterized by terminal and intercalary chlamydospores. Germination of single terminal spores, sometimes from more than one point (Fig. 4, 7), may result in the continuation of the filament. Similar structures are known from extant ascomycetes and basidiomycetes. The form of the hyphae and the presence of wood decay suggests that the mycelium is not phycomycetous but rather is that of a higher fungus (ascomycete or basidiomycete). However, in 
the absence of clamp connections it is not possible to differentiate ascomycete and basidiomycete on the basis of hyphal morphology (Roff, 1964), and neither ascocarps nor basidiocarps have been observed.

The surface texture of the hyphae is another interesting feature. Considerable variability in surface morphology exists in extant hyphae. For example, among hyphae with a rough texture are the terminal hairs of thermophilic species of Chaetonium Kunze ex Fr. (Hawksworth and Wells, 1973; Ellis, 1981). Hawksworth and Wells (1973) described 10 types of ornamentation, several of which are similar to that seen among the roughest hyphae in $\mathrm{Cal}$ lixylon, but it appears that in Chaetonium this ornamentation is not a taxonomically useful feature (Ellis, 1981). Similar excrecences can also be found on conidia of several imperfect fungi (Reisinger and Kiffer, 1974) and on peridial hyphae and appendages of Pseudogymnoascus roseus Raillo (Tsuneda, 1982). In each case they are produced by the fungus. However, hyphae may also be encrusted with degradation products in decaying wood, and it is interesting that the roughest hyphae occur in the ray cells that contain large amounts of possible ergastic material. Although there is always the possibility of more than one type of fungus in a piece of decayed fossil wood, the variability in surface morphology among the hyphae does not necessarily imply a variety of fungal types in the present material.

The contents of ray parenchyma cells, first noted by Arnold (1931), is probably the most distinctive and puzzling feature of this wood. Of the three types of bodies found in these cells, the first two types are highly variable in size and shape and, therefore, are probably nonfungal despite the resemblance of the smaller spherical bodies to spores. On the basis of comparison with permineralized Carboniferous fossils, this material may be an ergastic product or resinous compound. The origin of the hyaline layer around certain bodies is unclear. However, because it encases material of all sizes and shapes it is unreasonable to regard it as a fungal spore or a hyphal sheath.

The search for modern analogs is inconclusive. However, similar bodies have been reported from root cells of mycorrhizal Pinus mugo (Wills and Cole, 1978). These structures, referred to as "vesicular bodies" (Wills and Cole, 1978), are highly variable in size and shape. Large vesicles sometimes appear to be formed by the coalescence of smaller ones. As in the present material, some are smooth while most are rough, closely resembling the warty appearance of the fungal hyphae in the same tissue. These bodies are spatially associated with the Hartig net. Among other possibilities, Wills and Cole (1978) suggest that the bodies may be an adcrusting deposit similar to that reported in wheat caryopsis (Zee, 1975), although they are ultimately uncertain about their origin and function. The accumulation of resinous material in tracheids and ray parenchyma has also been observed in other instances of wood decay. Blanchette (1979) describes this in the degradation of several types of gymnosperms by Phellinus pini (Thore ex Fr.) A. Ames and suggests that this appears to be a host response to infection. The conspicuous nonfungal bodies in the ray cells of $\mathrm{Cal}$ lixylon newberryi can also be hypothesized to be a response to fungal infection. However, observations of apparently uninfected wood of this species from three different localities do not support this hypothesis since the rays in these wood samples also contain similar inclusions. These observations do not nullify the hypothesis, however, since a fungal infection some distance away might have had a physiological effect in the region of wood sectioned.

The third type of structure is found in both the ray cells and tracheids but is much less common than the first two. They are generally spherical, but are often wrinkled, as though they may have shrunken or collapsed during fossilization. It is possible that some of these bodies are fungal reproductive structures. Unfortunately, they are always discrete, and there is no evidence of germination. Nevertheless, chlamydospores have been found in attachment to hyphae, and it would not be unreasonable to find isolated spores in either the rays or tracheids. Alternatively, these structures may be related to the hyaline regions surrounding many spheres, although they are typically thinner walled than these structures, apparently smooth, and more numerous in the tracheids than dark spheres.

The fossil record has traditionally provided little information concerning the evolution of fungi (Bartnicki-Garcia, 1970). Several authors have suggested an early, possibly Precambrian, origin for primitive fungi (e.g., Tyler and Barghoorn, 1954; Pflug, 1964; Schopf and Barghoorn, 1969; Timofeev, 1970; Pflug and von Klopotek, 1978), while others question these reports (Tiffney, pers. comm.). However, by the end of the Paleozoic major fungal groups are represented, but the changes that occurred between the Precambrian and the end of the Paleozoic are poorly documented. Our present knowledge of the Devonian mycoflora suggests the existence of oomycetes and zygomycetes (Kidston and Lang, 1921; Butler, 1938), which 
may be endomycorrhizal (Boullard and Lemoigne, 1971; Pirozynski and Malloch, 1975; Wagner and Taylor, 1982) as well as possible chytrids or hyphochytrids (Illman, 1984). However, the higher fungi are not customarily associated with the Devonian. The first generally accepted basidiomycetes are known from Pennsylvanian hyphae with clamp connections (Dennis, 1970), while there has been little agreement concerning the time of origin of the ascomycetes. While some argue for the presence of Carboniferous ascomycetes (Stubblefield and Taylor, 1983a, b; see also Tiffney and Barghoorn, 1974), others are skeptical of past reports and have suggested that undisputed ascomycetes have not been found in the Paleozoic (Pirozynski, 1976). Recently, however, Sherwood-Pike and Gray (1985) have documented the existence of probable ascomycetes from the Silurian of Gotland. The fossil record of the Devonian mycoflora, then, consists primarily of a very few reports of lower fungi. We believe that this this is an inaccurate reflection of fungal diversity during the Devonian and a poor indication of the geological range of the higher fungi. The morphological and taxonomical complexity exhibited by the late Devonian vascular flora suggests the availability of a variety of substrates and a high potential for plant/fungi interactions. Vascular land plants arose by the end of the Silurian, secondary xylem had evolved by the Eifelian, and arborescent plants with extensively developed secondary xylem and phloem were present by the Givetian (Banks, 1980). Furthermore, spores, broad megaphylls, periderm and seeds, all substrates for fungi today, existed by the close of the Devonian. In light of the varied interactions that exist between fungi and vascular plants today, it would not be surprising to find parasites, pathogens, leaf-inhabiting fungi, mycorrhizae, or saprophytes, including wood-decaying fungi far earlier than the middle Pennsylvanian.

Speculation on the origin of higher fungi has, of necessity, been based on modern forms. However, the fossil record may yet provide valuable data concerning the time of origin of major groups and their eventual diversification. The present material is particularly encouraging in suggesting the existence of Devonian fungi, probably ascomycetes or basidiomycetes, which interacted with early land plants in a manner similar to modern-day fungi. This material also leads us to expect greater diversity in the Devonian mycoflora and suggests that the earliest land plants may be a fruitful source of information concerning the origin of fungi adapted to life on land.

\section{LITERATURE CITED}

ARnold, C. A. 1931. On Callixylon newberryi (Dawson) Elkins et Wieland. Contrib. Mus. Paleontol. Univ. Mich. 3(12): 207-232.

BANks, H. P. 1980. Floral assemblages in the SiluroDevonian. In D. Dilcher and T. N. Taylor [eds.], Biostratigraphy of fossil plants, pp. 1-24. Dowden, Hutchinson and Ross, Stroudsburg, $\mathrm{Pa}$.

BARTNICKI-GarCIA, S. 1970. Cell wall composition and other biochemical markers in fungal phylogeny. In $\mathrm{J}$. B. Harborne [ed.], Phytochemical phylogeny, pp. 81103. Academic Press, London.

Blanchette, R. A. 1979. Wood decomposition by Phellinus (Fomes) pini: a scanning electron microscopy study. Can. J. Bot. 58: 1496-1503.

Boullard, B., AND Y. Lemoigne. 1971. Les champignons endophytes du "Rhynia gwynne-vaughanil" $\mathrm{K}$. et L. Botaniste 14: 49-89.

Bravery, A. F. 1971. The application of scanning electron microscopy in the study of timber decay. J. Inst. Wood Sci. 5: 13-19.

BUTLER, E. J. 1938. The occurrences and systematic position of the vesicular-arbuscular type of mycorrhizal fungi. Trans. Br. Mycol. Soc. 22: 274-301.

Collinson, C. 1967. Devonian of the north central region of the United States. In D. H. Oswald [ed.], International symposium on the Devonian system, pp. 933-971. Can. Soc. Pet. Geol., Calgary, Alberta.

CORBETT, N. H. 1965. Micro-morphological studies on the degradation of lignified cell walls by ascomycetes and fungi imperfecti. J. Inst. Wood Sci. 14: 18-29.

DenNis, R. L. 1970. A Middle Pennsylvanian basidiomycete mycelium with clamp connections. Mycologia 62: 578-584.

ElLIs, D. H. 1981. Ascocarp morphology and terminal hair ornamentation in thermophilic Chaetomium species. Mycologia 73: 755-773.

Eriksson, K., A. Grunwald, T. Nillson, and L. ValLENDER. 1980. A scanning electron microscopy study of the growth and attack on wood by three white-rot fungi and their cellulase-less mutants. Holzforschung 34: 207-213.

Findlay, G. W. D., ANd J. F. Levy. 1969. Scanning electron microscopy as an aid to the study of wood anatomy and decay. J. Inst. Wood Sci. 23: 57-63.

Fry, W. L., AND D. J. MCLAReN. 1959. Fungal filaments in a Devonian limestone from Alberta. Can. Geol. Surv. Bull. 48: 1-9.

Harvey, R., A. G. Lyon, ANd P. N. Lewis. 1969. A fossil fungus from Rhynie chert. Trans. Br. Mycol. Soc. 53: 155-157, Pl. 16.

Hawksworth, D. L., and H. Wells. 1973. Ornamentation on the terminal hairs in Chaetomium Kunze ex Fr. and some allied genera. Mycol. Pap. 134: 124.

ILLMAN, W. I. 1984. Zoosporic fungal bodies in the spores of the Devonian fossil vascular plant, Horneophyton. Mycologia 76: 545-547.

JutTe, S. M., AND R. A. ZABel. 1974. Initial wood decay stages as revealed by scanning electron microscopy. Scanning electron microsc. 1974 (Part II): 445-452.

KIDSTON, R., AND W. H. LANG. 1921. On Old Red Sandstone plants showing structure, from the Rhynie Chert Bed, Aberdeenshire. V. The Thallophyta occurring in the peat-bed; the succession of the plants through a vertical section of the bed, and the conditions of accumulation and preservation of the deposit. Trans. R. Soc. Edinburgh 52: 855-902, Pl. I-X. 
Levy, J. F. 1974. Fungi in wood. Scanning electron microsc. 1974 (Part II): 461-468.

. 1982. The place of basidiomycetes in the decay of wood in contact with the ground. In J. C. Frankland, J. N. Hedger, and M. J. Swift [eds.], Decomposer Basidiomycetes, pp. 161-178. Cambridge University Press, Cambridge, U.K.

Montgomery, R. A. P. 1982. The role of polysaccharidase enzymes in the decay of wood by basidiomycetes. In J. C. Frankland, J. N. Hedger, and M. J. Swift [eds.], Decomposer Basidiomycetes, pp. 51-65. Cambridge University Press, Cambridge, U.K.

Pflug, H. D. 1964. Niedere Algen und ähnliche Kleinformen aus dem Algonkium der Belt-Serie. Ber. Oberhess. Ges. Nat.-u. Heilk. 33: 403-411.

- , AND A. vON KLOPOTEK. 1978. Eucaryonten im Archaikum? Oberhess. Naturwiss. Z. 44: 19-28.

Pirozynski, K. A. 1976. Fossil fungi. Annu. Rev. Phytopathol. 14: 237-246.

- AND D. W. MALLOCH. 1975. The origin of land plants: a matter of mycotrophism. BioSystems 6: 153164.

ReISINGER, O., AND E. KIfFER. 1974. Contribution to the fungal microflora of the Congo. IV. Polyschema congolensis sp. nov.: Taxonomy and ultrastructure. Trans. Br. Mycol. Soc. 62: 289-294.

RoFF, J. W. 1964. Hyphal characteristics of certain fungi in wood. Mycologia 56: 799-804.

SAvORY, J. G. 1954. Breakdown of timber by Ascomycetes and Fungi Imperfecti. Ann. Appl. Bot. 41: 336-347.

SCHOPF, J. W., AND E. S. BARghOORN. 1969. Microorganisms from the late Precambrian of South Australia. J. Paleontol. 43: 111-118.

Sherwood-Pike, M. A., AND J. Gray. 1985. Silurian fungal remains: probable records of the class Ascomycetes. Lethaia 18: 1-20.
Skog, J. E. 1983. Callixylon wood from the Greenland Gap Group (Upper Devonian) of southwestern Virginia. Va. J. Sci. 34: 58-64.

Stubblefield, S. P., ANd H. P. Banks. 1983. Fungal remains in the Devonian trimerophyte Psilophyton dawsonii. Amer. J. Bot. 70: 1258-1261.

- , AND T. N. TAYLOR. 1983a. Studies of Paleozoic fungi. I. The structure and organization of Traquairia (Ascomycota). Amer. J. Bot. 70: 387-399.

— AND —. 1983b. Studies of Carboniferous fungi. II. The structure and organization of Mycocar pon, Sporocarpon, Dubiocarpon, and Coleocarpon (Ascomycotina). Amer. J. Bot. 70: 1482-1498.

TAYLOR, B. J. 1971. Thallophyte borings in phosphatic fossils from the Lower Cretaceous of southeast Alexander Island, Antarctica. Palaeontology 14: 294-302.

TiffNeY, B. H., AND E. S. Barghoorn. 1974. The fossi] record of the fungi. Occas. Pap. Farlow Herb. Cryptogam. Bot. Harv. Univ. 7: 42 .

Timofeev, B. V. 1970. Une découverte de phycomycetes dans le Precambrien. Rev. Palaeobot. Palynol. 10: 7981.

TSunEDA, A. 1982. Scanning electron microscopy of Pseudogymnoascus roseus. Mycologia 74: 844-847.

Tyler, S. A., AND E. S. BarghoORN. 1954. Occurrences of structurally preserved plants in Precambrian rocks of the Canadian Shield. Science 119: 606-608.

WAGNer, C. A., AND T. N. TAYLOR. 1982. Fungal chlamydospores from the Pennsylvanian of North America. Rev. Palaeobot. Palynol. 37: 317-328.

WILls, B. J., AND A. L. J. COLE. 1978. A scanning electron microscopy study of 'vesicular bodies' in mycorrhizal roots of Pinus mugo (Turra). New Phytol. 80: 579582 .

ZEE, S. Y. 1975. Scanning microscope observations of the pigment strand in the caryopsis of wheat. Aust. J. Bot. 23: 107-110. 